\title{
ALTERNATIVAS DE INVESTIMENTOS ÀS PESSOAS FÍSICAS E O PERFIL DE INVESTIDOR DOS ACADÊMICOS DE CIÊNCIAS CONTÁBEIS DA UNEMAT, CAMPUS DE TANGARÁ DA SERRA-MT
}

\author{
Gabriel Batista da Silva ${ }^{1}$ \\ Flavio Amaral Oliveira ${ }^{2}$
}

\begin{abstract}
RESUMO
O objetivo geral desta pesquisa foi apresentar alternativas de investimentos disponíveis no mercado financeiro brasileiro, destinadas às pessoas físicas, e também, identificar o perfil investidor dos acadêmicos do $6^{\circ}, 7^{\circ}$ e $8^{\circ}$ semestres do curso de ciências contábeis da UNEMAT, do campus de Tangará da Serra - MT. A pesquisa apresentou informações sobre os tipos de riscos a que os investimentos estão sujeitos e sobre os perfis de investidores. A metodologia adotada foi a pesquisa exploratória, qualitativa, bem como a descritiva, quantitativa, e em relação ao objeto de estudo classificou-se como bibliográfica e pesquisa de campo. Foram destacadas 06 (seis) opções de investimentos, sendo elas: Caderneta de Poupança; Títulos Públicos; Fundos de Investimentos; Ações; CDBs e RDBs; e Previdência Privada. Identificou-se menos 05 (cinco) tipos de riscos aos quais os investimentos estão sujeitos, sendo eles: Risco de Mercado; de Liquidez; de Crédito; Operacional e Legal. Verificou-se que existem 03 (três) perfis de investidores, sendo eles: Conservador; Moderado; e Arrojado ou Agressivo. Em relação ao perfil investidor dos acadêmicos do curso de Ciências Contábeis da UNEMAT, identificou-se que o perfil de investidor conservador prevaleceu na maioria dos acadêmicos.
\end{abstract}

Palavras-chave: Investimentos. Mercado Financeiro. Pessoas Físicas (PF). Perfil do Investidor. Decisões.

\section{INTRODUÇÃO}

A informação tornou-se elemento básico para os investidores uma vez que os mesmos precisam levar em conta vários fatores na hora de investir para decidir onde aplicar os seus recursos. Assim, é necessário conhecer todas as opções disponíveis no mercado financeiro e em muitas vezes é preciso buscar a ajuda de profissionais que atuem nesse mercado, que possuam conhecimentos das opções existentes e que saibam também identificar o perfil dos investidores e o grau de risco que os mesmos estão dispostos a correr na busca de uma maior rentabilidade para suas aplicações (ANDREATTA et al., 2009).

Comparando-se aos países da América Latina, o Brasil é o país que tem o menor número relativo de investidores, onde menos de $0,4 \%$ da população investem na Bovespa, a qual possui 590 mil investidores pessoas físicas e parece não explorar bem o seu potencial. Como exemplo, na Colômbia 2,4\% da população total do país (equivalente a 1,1 milhões de

1 Acadêmico do curso de Ciências Contábeis da UNEMAT - Campus de Tangará da Serra, e-mail: gabriel.paco@hotmail.com

2 Professor do curso de Ciências Contábeis da UNEMAT - Campus de Tangará da Serra, e-mail: flavioamaral@unemat.br

Volume 3, Número 5

Revista UNEMAT de Contabilidade

Jan./Jun. 2014

UNEMAT 
Alternativas de investimentos às pessoas físicas e o perfil de investidor dos acadêmicos de ciências contábeis da UNEMAT, campus de Tangará da Serra-MT

Gabriel Batista da Silva

Flavio Amaral Oliveira

investidores pessoas físicas) investe em ações. Já no Panamá, considerando que a população desse país da América Central é de apenas 3,5 milhões, cerca de, 75 mil investem em ações (LIRA, 2012).

E para Elvira Schamann, secretaria da Federação Iberoamericana de Bolsas (Fiab), os países onde o mercado de capitais encontra-se mais disponível para as pessoas físicas são Colômbia e Chile onde de acordo com Gonçalo Encinas, presidente do Comitê de Trabalho do Fiab, quase $4 \%$ da população total do Chile investe em ações, o que equivale a 600 mil investidores pessoas físicas, caso considere-se os investidores em fundos e fundos de pensão os números chegam a 1,4 milhões da população. E apesar de imprecisos, estima-se que na Argentina existam cerca de 750 mil investidores e no México aproximadamente 0,65\% da população investem em ações, percentual que representa de 400 a 500 mil pessoas (LIRA, 2012).

Sob a perspectiva de Rocha (2013), desde 2008 o volume de negócios realizados na Bolsa BM\&F Bovespa está estagnado e apesar do crescimento do volume financeiro da bolsa brasileira em 24,5\% desde a crise de 2008 passando de $\mathrm{R}$ \$ 1,2 trilhão para R \$ 1,5 trilhão, caso se ajuste esses números pelo IPCA do período ver-se-á que o volume de 2012 foi semelhante ao de 2008 em torno de $\mathrm{R} \$ 1,5$ trilhão. De acordo com o autor, no período compreendido em 2003 a 2007, a bolsa passou por uma ótima fase, onde 106 novas companhias abriram o capital, assim a rentabilidade do Ibovespa e o investidor pessoa física contribuiu com esse sucesso, onde o número de cadastros cresceu 528\% passando de 85 mil em 2003 para 536 mil em 2008, porém a crise de 2008 afetou a situação. Em 2010, o número de investidores pessoas físicas atingiu 610 mil, entretanto em 2012 fechou em 587 mil e com a saída desse tipo de investidor, o volume negociado na bolsa só continuou constante devido ao aumento dos investimentos estrangeiros.

A realização deste estudo é importante e justifica-se pela possibilidade de proporcionar informações a respeito das opções de investimentos disponíveis no mercado para o público investidor PF. Espera-se também contribuir de forma que novos estudos nessa área possam ser desenvolvidos nos contextos acadêmicos, incentivando assim o interesse e desafio por assuntos na área financeira contribuindo também para a formação dos profissionais em Contabilidade. Este trabalho não se encerra por si mesmo, ficando assim o espaço para novos estudos e informações. 
Alternativas de investimentos às pessoas físicas e o perfil de investidor dos acadêmicos de ciências contábeis da UNEMAT, campus de Tangará da Serra-MT

Gabriel Batista da Silva

Flavio Amaral Oliveira

O objetivo geral desse estudo foi apresentar alternativas de investimentos disponíveis no mercado financeiro brasileiro, destinadas às pessoas físicas, e também, identificar o perfil investidor dos acadêmicos do $6^{\circ}, 7^{\circ}$ e $8^{\circ}$ semestres do curso de Ciências Contábeis da UNEMAT, campus de Tangará da Serra - MT. Através de objetivos específicos, pesquisou-se as características das alternativas de investimento mais comuns no mercado financeiro; identificou-se os tipos de risco a que os investimentos estão sujeitos; pesquisou-se as características dos perfis de investidores; e verificou-se qual é o perfil de investidor dos acadêmicos de Ciências Contábeis.

\section{REFERENCIAL TEÓRICO}

\subsection{Mercado Financeiro Brasileiro}

O mercado financeiro é o local onde os investidores procuram alcançar rentabilidade através de aplicações financeiras, sendo assim um ambiente favorável para se ganhar dinheiro. As taxas que servirão de base para remuneração dos recursos aplicados, bem como o prazo em que a rentabilidade será alcançada são algumas das principais preocupações de qualquer investidor no momento em que se vai ao mercado procurar algum tipo de investimento para aplicar os seus recursos (CARNEIRO, 2012).

Na segunda metade de 2011 o Mercado Financeiro Internacional demonstrou sinais fortes de instabilidade e ainda se recupera desse momento negativo, porém não houve grande impacto negativo no mercado brasileiro como imaginavam alguns especialistas. $\mathrm{O}$ aumento de forma sustentada da renda média das famílias brasileiras, proporcionando um maior poder de compra da maioria da população, a criação de novas linhas de crédito que incentivaram o empreendedorismo e o nível baixo de desemprego são alguns indicadores que mostram que o mercado financeiro passa por um bom momento (VIEIRA, 2013).

Já sob a ótica de Veríssimo (2013), existem muitas barreiras como a baixa renda dos brasileiros, o pequeno nível de poupança e a intensidade fiscal brasileira que dificultam o desenvolvimento do mercado brasileiro, além do fato de que o déficit governamental é pago pela poupança privada. Além dessas barreiras, existe uma série de deficiências no mercado de capitas, a exemplo da fragilidade da proteção legal para os investidores no Brasil, onde ano após ano várias empresas abertas enganam seus investidores minoritários e outra deficiência é a volatilidade do mercado, que representa um alto risco para os investidores individuais, 
Alternativas de investimentos às pessoas físicas e o perfil de investidor dos acadêmicos de ciências contábeis da UNEMAT, campus de Tangará da Serra-MT

Gabriel Batista da Silva

Flavio Amaral Oliveira

reduzindo assim o incentivo de investimentos. Porém o autor coloca ainda que, mesmo com todas as suas particularidades, sendo algumas negativas, o mercado financeiro brasileiro é atrativo e seu futuro aparenta ser promissor mesmo se desenvolvendo lentamente.

\subsection{Investimentos}

Investimentos representam a aplicação de capital em alternativas que promovem o aumento efetivo da capacidade produtiva de um país e aumentam a geração de riquezas. Num sentido mais amplo, investir significa direcionar os recursos para a obtenção de juros e lucros (ASSAF NETO, 2005, p. 28 apud CADORE, 2007, p. 18).

A Caixa Econômica Federal (2013), destaca cinco motivos para que as pessoas invistam, sendo eles: aumentar o poder de poupança, formar patrimônio, realizar sonhos, garantir o futuro e proporcionar tranquilidade para a família e os filhos.

\subsection{Principais opções de investimentos para pessoas físicas}

De acordo com o Banco Central do Brasil - BACEN (2013), a poupança, o Certificado de Depósito Bancário (CDB), o Recibo de Depósito Bancário (RDB) e os Fundos de Investimento são as opções de investimentos mais comuns.

\subsubsection{Caderneta de Poupança}

A origem da caderneta de poupança deu-se ainda no século XIX com a criação da Caixa Econômica da Corte pelo Decreto $\mathrm{n}^{\circ} 2.723$, de 12 de janeiro de 1861, a qual foi criada principalmente para receber os depósitos dos brasileiros, especialmente daqueles que formavam as classes sociais menos favorecidas. Inicialmente a remuneração dos depósitos recebidos não poderia ser superiores a $6 \%$ ao ano, e a taxa de juros era definida anualmente (CAIXA ECONÔMICA FEDERAL, 2013).

Em 1964, através da Lei no 4.380, de 21 de agosto de 1964, foi instituída a correção monetária sobre os depósitos. Assim, além da remuneração anual de $6 \%$ ao ano $(0,5 \%$ ao mês), os valores passaram a ser corrigidos mensalmente pela correção monetária, a qual tem seus valores definidos pelo Banco Central do Brasil. Já em 1991, com a criação da Lei 8.177 de 01 de março de 1991, a poupança passou a ser remunerada mensalmente a uma taxa de juros de 0,5\% aplicada sobre os valores corrigidos pela Taxa Referencial (TR) (CAIXA ECONÔMICA FEDERAL, 2013).

Ainda conforme a CAIXA (2013), com a criação da Medida Provisória 567/2012, a partir de 03 de maio de 2012, a remuneração da poupança passou a ser da seguinte forma: 
Alternativas de investimentos às pessoas físicas e o perfil de investidor dos acadêmicos de ciências contábeis da UNEMAT, campus de Tangará da Serra-MT

Gabriel Batista da Silva

Flavio Amaral Oliveira

a) Continuará sendo remunerada a $0,5 \%$ a.m. mais correção da TR, enquanto a Meta da Taxa SELIC for maior do que 8,5\% a.a.

b) Será remunerada em $70 \%$ da Taxa SELIC meta a.a, em forma mensal, vigente no início do período de rendimento mais TR, quando a Meta da Taxa SELIC for igual ou inferior a $8,5 \%$ a.a.

Mesmo com as mudanças nas regras de remuneração da poupança, os brasileiros ainda preferem aplicar nesta opção de investimento e a captação liquida das cadernetas no Brasil apresentou o melhor mês de junho e primeiro semestre da série histórica do Banco Central que se iniciou em 1995. Nos seis primeiros meses do ano, a captação líquida da poupança atingiu R\$28,273 bilhões e foi recorde para o semestre (BRANCO, 2013).

\subsubsection{Títulos Públicos}

Para Andreatta et al (2009), o Tesouro Nacional emite os títulos públicos para captar recursos que ajudem a financiar as atividades do Governo Federal como educação, saúde e infraestrutura e para fortalecer a economia do Brasil. Além disso, são resgatados por um valor certo em data predeterminada podendo ou não serem atualizados por índices de mercado e sua venda é realizada no Brasil através de três modalidades, sendo elas a) oferta pública com a realização de leilão, b) oferta pública sem a realização de leilão (Tesouro Direto) e c) Em emissões diretas para atender as demandas especificas determinadas em lei

De acordo com o Tesouro Nacional (2013), são ativos de renda fixa, pois seus rendimentos podem ser estimados na hora do investimento, diferentemente dos ativos de renda variável, como por exemplo, as ações, onde não se pode estimar o retorno no momento da realização do investimento, é considerado investimento do tipo conservador devido à volatilidade dos ativos de renda física ser menor que a dos ativos de renda variável, desta forma esse tipo de investimento possui riscos menores. Podem ser emitidos na modalidade pré-fixada onde a taxa de rentabilidade é determinada na hora da compra, ou na modalidade pós-fixada, onde o valor do título é corrigido por um indexador, como os índices de preços e a taxa Selic, podendo ainda ser de curto, médio ou longo prazo e são considerados como os ativos de menor risco da economia de um País, sendo garantidos em 100\% pelo Tesouro Nacional.

As principais vantagens dos títulos públicos são a segurança e o custo de aquisição, pois possuem baixíssimos riscos já que são emitidos pelo governo e é de aproximadamente 
Alternativas de investimentos às pessoas físicas e o perfil de investidor dos acadêmicos de ciências contábeis da UNEMAT, campus de Tangará da Serra-MT

Gabriel Batista da Silva

Flavio Amaral Oliveira

$0,5 \%$ a.a o custo de aquisição, o qual é bem menor que os custos de administração dos fundos de investimentos que podem chegar até $4 \%$ ao ano. E ainda são comprados pela internet através do Tesouro Direto após realização de cadastro em uma corretora que esteja autorizada a negociar esses papéis (FRANCO, 2010).

Ainda de acordo com Franco (2010, p.2), os principais tipos de títulos públicos são:

a) Letras do Tesouro Nacional: papel pré-fixado, a taxa correspondente depende da validade do título. Esses estão pagando uma taxa que varia entre $11,13 \%$ a.a. com vencimento em janeiro de 2011 e $12,67 \%$ a.a. para vencimento em janeiro de 2013. Nada mal comparados aos $6 \%$ a.a. da caderneta de poupança.

b) Notas do Tesouro Nacional: esse título é um mix entre pré e pós-fixado, sua rentabilidade acompanha a variação do IPCA, acrescida de juros previamente acordado no momento da compra. A rentabilidade pré-fixada está na casa dos $6,5 \%$ ao ano, considerando um IPCA de 5,2\% (estimativa para este ano), esse título renderia para o investidor aproximadamente $11,7 \%$.

c) Letras Financeiras do Tesouro: título com rentabilidade diária, cuja rentabilidade acompanha a taxa básica de juros da economia (taxa SELIC).

\subsubsection{Fundos de Investimentos}

Os fundos de investimento funcionam como um condomínio que utiliza os recursos de um grupo de investidores denominados cotistas, onde o objetivo é proporcionar rentabilidade para os mesmos por meio da aquisição de uma carteira de títulos ou valores mobiliários. Normalmente, os cotistas de um fundo possuem os mesmos objetivos e interesses quando investem seus recursos no mercado financeiro e de capitais. Ao aplicar seus recursos nessa opção de investimento, o investidor adquire uma quantidade de cotas e concorda com as regras de funcionamento do fundo, (valores, horários, prazos de liquidação das aplicações e de seu direcionamento, resgates, rateios das despesas, taxa de administração, etc.) (BOVESPA, 2012).

Em uma definição mais simples, Eid Júnior (2012) diz que é um investimento feito por um grupo de pessoas por isso é possível que elas invistam em produtos melhores, tenham menores custos e melhores retornos.

Conforme a Comissão de Valores Mobiliários - CVM (2013), normalmente os fundos podem ser organizados sob a forma de condomínios abertos ou fechados os quais são definidos abaixo:

\section{a) Fundos Abertos}

Permite-se a entrada ou a saída de novos cotistas, bem como o aumento da participação dos antigos através de novos investimentos. A saída de um cotista acontece com 
Alternativas de investimentos às pessoas físicas e o perfil de investidor dos acadêmicos de ciências contábeis da UNEMAT, campus de Tangará da Serra-MT

Gabriel Batista da Silva

Flavio Amaral Oliveira

o resgate de cotas, onde o fundo realiza a venda de ativos para entrega do valor ao cotista. Normalmente essa forma de fundo é criada para existir por tempo indeterminado.

\section{b) Fundos Fechados}

Não se permite a entrada e/ou saída de cotistas nem o aumento de participação dos cotistas existentes. Também não é admitido o resgate de cotas, caso o investidor queira se retirar do fundo deverá vender suas cotas a terceiros para receber o valor investido antes do término do fundo. Normalmente essa modalidade de fundo é constituída por prazo determinado, onde no encerramento do fundo os cotistas recebem o valor referente às suas cotas.

Ainda de acordo com a CVM (2013), a principal vantagem dos fundos é a possibilidade que tem os investidores de perfis semelhantes, com objetivos comuns, mesmo nível de tolerância ao risco, e estratégias de investimentos semelhantes reunirem recursos, aumentando o poder de negociação e diluindo os custos de administração. Já as desvantagens estão no fato do investidor precisar delegar a terceiros a administração dos recursos, não possuir autonomia para tomar decisões e se submeter às regras previamente estabelecidas e a vontade da maioria dos cotistas. A comissão define ainda que existem sete classes de fundos de investimentos conforme abaixo:

a) Fundo de Curto Prazo;

b) Fundo Referenciado;

c) Fundo de Renda Fixa;

d) Fundo de Ações;

e) Fundo Cambial;

f) Fundo de Dívida Externa; e

g) Fundo Multimercado.

EID JUNIOR (2012) coloca ainda que no mundo existe cerca de 70.000 fundos formando um patrimônio com 25,6 trilhões de dólares ou cerca de 10 vezes o Produto Interno Bruto (PIB) do Brasil. Há no Brasil mais de 8.000 fundos que representam um patrimônio líquido de 1,7 trilhões de reais, onde cerca de 2.000 deles podem ser captados e isso classifica o Brasil como a quinta maior indústria de fundos do mundo.

\subsubsection{Ações}

De acordo com a BOVESPA (2010, p.17):

Ações são títulos de renda variável, emitidos por sociedades anônimas, que representam a menor fração do capital da empresa emissora. Podem ser escriturais ou representadas por cautelas ou certificados. O investidor de ações é um co- 
Alternativas de investimentos às pessoas físicas e o perfil de investidor dos acadêmicos de ciências contábeis da UNEMAT, campus de Tangará da Serra-MT

Gabriel Batista da Silva

Flavio Amaral Oliveira

proprietário da sociedade anônima da qual é acionista, participando dos seus resultados. As ações são conversíveis em dinheiro, a qualquer tempo, pela negociação em bolsa ou no mercado de balcão.

São dois os tipos básicos de ações: As preferenciais $(\mathrm{PN})$ e as ordinárias $(\mathrm{ON})$, o primeiro tipo em caso de falência da companhia dá preferência ao receber os dividendos e juros, bem como no reembolso do valor investido, porém não dão direito a voto. Já o segundo tipo é aquele que dar o direito a voto nas assembléias da companhia. Além dos tipos básicos apresentados, há outra denominação dada quando o investidor aplica seus recursos em ações que são negociadas em conjunto, que é a "Unit" que são ativos com mais de uma classe de valores imobiliários negociadas em grupo, porém são compradas e vendidas no mercado como unidade (SANTOS, 2011).

O fluxo de oferta e procura de cada papel é determinado pelos investidores do mercado através das ordens de compra ou venda que são passadas às corretoras, assim, o preço justo da ação é estabelecido. É a maior ou menor procura e oferta que influencia o processo de valorização ou desvalorização de uma ação e está relacionada à análise técnica (histórico do comportamento dos preços) e principalmente à análise fundamentalista (perspectivas futuras de desempenho da empresa emissora da ação) [...] (BOVESPA, 2008 apud FERREIRA et al., 2008).

Para Martins (2013, p.1), existem duas escolas de análises que ajudam a escolher os ativos que comporão uma carteira de investimento em ações, são elas:

Análise Fundamentalista: Através da interpretação de dados e indicadores disponibilizados pela empresa e tidos como válidos essa escola considera os seus fundamentos. Entretanto, existem controvérsias nas interpretações, implicando na dificuldade de se prever o comportamento dos preços dos ativos e inclusive há a possibilidade de encontrar dados 'maquiados' nos balanços e demonstrações de resultado de exercício (DRE) das empresas analisadas [...].

Análise Gráfica: também conhecida como análise técnica, essa escola acredita que todos os fatores necessários para análise dos ativos estão representados nos gráficos, acredita também que o comportamento do mercado pode ser encontrado nesses gráficos, sendo possível assim avaliar a participação de investidores que influenciam na formação dos preços. 
Alternativas de investimentos às pessoas físicas e o perfil de investidor dos acadêmicos de ciências contábeis da UNEMAT, campus de Tangará da Serra-MT

Gabriel Batista da Silva

Flavio Amaral Oliveira

\subsubsection{Certificados e Recibos de Depósitos Bancários (Renda Fixa)}

Os Certificados de Depósitos Bancários (CDBs) são títulos escriturais utilizados para captação de recursos pelos bancos comerciais e múltiplos, regulamentados pela Lei 4.728/1965 e Resolução 18/1966 do Conselho Monetário Nacional. Há a incidência do IR sobre os ganhos brutos através de alíquotas decrescentes de acordo com o prazo de aplicação e no caso de resgate em prazo menor que 30 dias, há a incidência de IOF. Podem ser prefixados ou pós-fixados, não existe prazo mínimo para emissão de CDBs pré-fixados e para pós-fixados atrelados à taxa DI. Já quando o indexador utilizado é a Taxa de Juro de Longo Prazo (TJLP), o prazo mínimo é de 30 dias; quando é a Taxa Básica Financeira (TBF), o prazo é de dois meses; e por fim quando for atrelada a taxa de inflação, é de um ano o menor prazo para se investir (BOVESPA, 2012).

Já os Recibos de Depósitos Bancários (RDBs) são semelhantes aos CDBs, a principal diferença entre eles é que o CDB pode ser transferido para terceiros e o RDB é inegociável e intransferível e também não podem ser resgatados antes de seu vencimento. No caso do CDB, caso seja negociada o resgate antes de seu vencimento, a devolução é realizada com deságio, ou seja, perda de parte da remuneração obtida (BOVESPA, 2012; BACEN, 2013 e CVM, 2013).

O CDB e RDB são títulos de renda fixa que são emitidos por bancos. Nesse caso, o banco recebe o dinheiro investido como um empréstimo e paga juros por isso. Dessa forma, esses investimentos envolvem uma promessa de pagamento do valor investido no futuro juntamente como o valor referente à taxa de juros contratada na época da transação (CVM, 2013).

\subsubsection{Previdência Privada}

A previdência privada ou complementar é um sistema privado com o objetivo principal de complementar a renda recebida através da previdência pública. Levando-se em conta que na maioria das vezes a renda recebida pela previdência social não é suficiente para atender às necessidades das pessoas após a aposentadoria, principalmente pelo fato de que o valor recebido é inferior ao salário antes de se aposentar é que surgiu a necessidade de adquirir uma renda complementar (DEBIASI, 2004). 
Alternativas de investimentos às pessoas físicas e o perfil de investidor dos acadêmicos de ciências contábeis da UNEMAT, campus de Tangará da Serra-MT

Gabriel Batista da Silva

Flavio Amaral Oliveira

Ainda Conforme Debiasi (2004, p.4) a previdência privada se divide sem dois tipos, sendo eles: previdência privada fechada (fundos de pensão) e aberta (bancos, seguradoras e montepios) como descrito abaixo:

A previdência privada fechada é caracterizada pelo modelo empresarial, que é privado e facultativo, sendo destinado a funcionários de empresas ou instituições que patrocinam planos de aposentadoria.

A previdência privada aberta é caracterizada pelo modelo individual, que é privado e facultativo, sendo destinado a qualquer pessoa que sentir a necessidade de adquirir um plano de aposentadoria.

Existem, basicamente, dois tipos de planos disponibilizados pelas sociedades de previdência privada: o Plano Gerador de Benefício Livre (PGBL) e o Vida Gerador de Benefício Livre (VGBL) onde a principal diferença entre eles é na forma de tributação. No plano PGBL, é possível abater até $12 \%$ da renda bruta anual do imposto sobre a renda, é fiscalizado pelo Banco Central e administrado por empresa especializada na gestão de recursos de terceiros e comercializado por seguradoras, bancos, etc. e é indicado para as pessoas que declaram o imposto de renda pelo formulário completo. Já no VGBL, é recomendado para as pessoas que não possuem renda tributável, uma vez que não pode ser deduzido do imposto de renda mesmo sendo necessário pagar o Imposto sobre o ganho de capital (MARTINS, 2013).

Para Carneiro (2013), é necessário realizar cotações antes de contratar algum dos planos de previdência privada, pois há duas taxas que devem ser pagas a entidade de previdência, e normalmente varia entre as empresas, são elas:

a) Taxa de carregamento: utilizada pela entidade para custeamento de despesas incorridas na comercialização dos planos e prestação dos serviços e é descontada mensalmente sobre o valor de contribuição.

b) Taxa de Administração: cobrada anualmente sobre os recursos acumulados do fundo e é utilizada para pagamento do trabalho dos gestores responsáveis pela aplicação dos recursos.

\subsubsection{Quadro-Resumo dos Investimentos (principais características, formas de acesso e custos)}

Logo abaixo na tabela 1, encontra-se disposto um resumo sobre os investimentos pesquisados, onde além de apresentar as características das opções apresentadas, constam 
Alternativas de investimentos às pessoas físicas e o perfil de investidor dos acadêmicos de ciências contábeis da UNEMAT, campus de Tangará da Serra-MT

Gabriel Batista da Silva

Flavio Amaral Oliveira

algumas informações a respeito das principais formas de acesso e dos principais custos envolvidos nestas opções de investimentos.

Tabela 1. Resumo dos Investimentos (principais características, formas de acesso e custos).

\begin{tabular}{|c|c|c|c|}
\hline $\begin{array}{c}\text { Opções de } \\
\text { Investimentos }\end{array}$ & Características & Acesso & Custos \\
\hline Poupança & $\begin{array}{l}\text { Investimento do tipo conservador, de baixo risco e livre de } \\
\text { imposto sobre a renda, acessível a qualquer pessoa, possui } \\
\text { liquidez imediata. Os recursos aplicados são garantidos } \\
\text { pelo Fundo Garantidor de Crédito - FGC até o limite de } \\
\mathrm{R} \$ 70.000,00 \text { por CPF. A Caixa Econômica Federal é o } \\
\text { único banco que garante } 100 \% \text { do valor investido em } \\
\text { poupança. }\end{array}$ & $\begin{array}{l}\text { Bancos do } \\
\text { SBPE e as } \\
\text { CEs }\end{array}$ & Não Existem. \\
\hline $\begin{array}{l}\text { Títulos } \\
\text { Públicos }\end{array}$ & $\begin{array}{l}\text { Considerado do tipo conservador, dependendo do prazo do } \\
\text { investimento, possui baixos riscos, pois são garantidos em } \\
100 \% \text { pelo Governo Federal. São de renda fixa e as } \\
\text { negociações podem ser realizadas através do Tesouro } \\
\text { Direto na Internet, após realização do cadastro em uma } \\
\text { corretora. Normalmente o prazo de investimento varia de } \\
\text { curto a longo, dependendo das características de cada } \\
\text { título. }\end{array}$ & $\begin{array}{c}\text { Corretoras e } \\
\text { Tesouro } \\
\text { Direto }\end{array}$ & $\begin{array}{c}\text { Custo de } \\
\text { Aquisição +/- } \\
0,05 \% \text { a.a }\end{array}$ \\
\hline $\begin{array}{c}\text { Fundos de } \\
\text { Investimentos }\end{array}$ & $\begin{array}{l}\text { O prazo desse tipo de investimento varia entre curto e } \\
\text { longo. É considerado de baixo risco, entretanto, possui } \\
\text { várias taxas que devem ser verificadas no regulamento de } \\
\text { cada modalidade. A suas principais vantagens reside na } \\
\text { possibilidade de diluição dos custos e do aumento do } \\
\text { poder de negociação, uma vez que é formado por um } \\
\text { grupo de investidores, com perfis, objetivos e nível de } \\
\text { tolerância aos riscos semelhantes. Dependendo do prazo, é } \\
\text { considerado investimento conservador, podendo também } \\
\text { ser Moderado. }\end{array}$ & $\begin{array}{c}\text { Bancos com } \\
\text { carteira de } \\
\text { Invest. }\end{array}$ & $\begin{array}{l}\text { Taxas de } \\
\text { Administração } \\
\text { e } \\
\text { Performance, } \\
\text { Entrada e } \\
\text { Saída, IOF* e } \\
\text { IR* }\end{array}$ \\
\hline Ações & $\begin{array}{l}\text { Investimento de renda variável, de alto risco e destinado } \\
\text { aos investidores com perfis mais agressivos. Por ser de } \\
\text { renda variável, sua rentabilidade nem sempre é certa, uma } \\
\text { vez que a mesma está atrelada a vários índices da } \\
\text { economia, como o Ibovespa, IBrX, IBrX-50 dentre outros. } \\
\text { Destinado às pessoas que querem investir em longo e que } \\
\text { estão dispostas a correrem maiores riscos e se sujeitar a } \\
\text { variações na rentabilidade. Entretanto é considerado um } \\
\text { investimento de alta rentabilidade. }\end{array}$ & $\begin{array}{l}\text { Bolsas de } \\
\text { Valores, } \\
\text { através das } \\
\text { Corretoras e } \\
\text { vendas em } \\
\text { Balcão. }\end{array}$ & $\begin{array}{c}\text { Taxas de } \\
\text { Corretagem e } \\
\text { Custódia e IR* }\end{array}$ \\
\hline CDBs e RDBs & $\begin{array}{l}\text { Investimentos de renda fixa, considerado de baixo risco, } \\
\text { destinado ao investidor com perfil conservador, o prazo de } \\
\text { aplicação varia entre médio e longo. Podem ser pré- } \\
\text { fixados ou pós-fixados e a principal diferença entre eles } \\
\text { reside no fato de que os CDBs podem ser transferidos para } \\
\text { terceiros, enquanto os RDBs são intransferíveis e } \\
\text { inegociáveis e não podem ser resgatados antes do } \\
\text { vencimento. }\end{array}$ & $\begin{array}{c}\text { Bancos } \\
\text { Comerciais } \\
\text { e Múltiplos }\end{array}$ & $\begin{array}{c}\text { IR* sobre } \\
\text { Ganhos Brutos } \\
\text { e IOF* (Resg. } \\
\text { Prazo menor } \\
\text { que } 30 \text { dias). }\end{array}$ \\
\hline $\begin{array}{l}\text { Previdência } \\
\text { Privada }\end{array}$ & $\begin{array}{l}\text { Essa opção de investimento destina-se às pessoas que } \\
\text { desejam ter uma renda complementar à renda recebida } \\
\text { para atender suas necessidades futuras. É do tipo renda } \\
\text { fixa, de longo prazo e possui baixo risco, também é } \\
\text { destinado ao investidor com perfil conservador e } \\
\text { moderado. }\end{array}$ & $\begin{array}{c}\text { Bancos e } \\
\text { Seguradoras }\end{array}$ & $\begin{array}{c}\text { Taxas de } \\
\text { Carregamento } \\
\mathrm{e} \\
\text { Administração }\end{array}$ \\
\hline
\end{tabular}

* IOF - Imposto sobre operações financeiras; IR - imposto sobre a renda.

Volume 3, Número 5

Revista UNEMAT de Contabilidade

Jan./Jun. 2014

UNEMAT 


\subsection{Riscos nos Investimentos}

De acordo com a visão de Carneiro (2012), o investidor deve ter pleno conhecimento sobre os riscos dos investimentos e é dever do administrador e ou analista de investimentos informarem a que riscos as aplicações financeiras estão sujeitas, mostrando assim que toda operação possui riscos em sua composição, os quais são inerentes ao valor aplicado, ao prazo de investimento e principalmente ao tipo de investimento em que se está aplicando os recursos. Ainda sob a visão do autor, as flutuações do mercado, as incertezas em relação à liquidez dos investimentos e também ao cumprimento das obrigações assumidas pela outra parte, são vistos como os riscos mais frequentes nas aplicações financeiras, configurando assim o risco de crédito.

Para D’Agosto (2011), o risco é avaliado pelos especialistas através de cinco diferentes perspectivas, sendo elas; mercado, crédito, liquidez, operacional e legal. Assim, a oscilação dos preços dos ativos é que determina o risco de mercado, que também é conhecido por volatilidade e quanto mais volátil for uma aplicação, mais risco terá. O prazo de aplicação também influencia nesse tipo de risco, sendo que quanto maior for o prazo maior será o risco de mercado. Em relação ao risco de crédito, o autor explica que é a possibilidade do investidor não receber o valor aplicado pelo fato da contraparte não poder honrar o compromisso.

Já o risco de liquidez está relacionado à possibilidade de que o investidor tenha que se desfazer de seus investimentos por conta de um momento ruim, como exemplo tem-se a necessidade da venda rápida de um imóvel, tendo que conceder grande desconto sobre o valor de avaliação uma vez que esse tipo de transação é normalmente demorado. O risco operacional está voltado à possibilidade de erros por parte de uma corretora, por exemplo, na execução das ordens dadas pelo investidor. E por fim, o risco legal está relacionado à falta de devida formalização dos investimentos (D’AGOSTO, 2011).

Em seu estudo sobre riscos nas aplicações financeiras e os fundos de investimentos, realizado em 2012, Wiliam Eid Júnior, professor titular e coordenador do Centro de Estudos em Finanças da Faculdade Getúlio Vargas - GVCEF também definiu que são cinco os riscos relacionados aos investimentos, sendo eles: Mercado, liquidez, crédito, operacional e legal. As definições e características dos tipos de riscos estão na tabela 2 logo abaixo: 
Alternativas de investimentos às pessoas físicas e o perfil de investidor dos acadêmicos de ciências contábeis da UNEMAT, campus de Tangará da Serra-MT

Gabriel Batista da Silva

Flavio Amaral Oliveira

Tabela 2. Riscos Associados aos Investimentos.

\begin{tabular}{|c|c|}
\hline Riscos & Definição \\
\hline MERCADO & $\begin{array}{l}\text { Relacionado às alterações dos preços, taxas de juros e câmbio. Pode ser medido levando-se } \\
\text { em conta a diferença entre o desempenho dos nossos investimentos e uma referência, } \\
\text { como por exemplo, a variação dos índices do certificado de depósito interbancário (CDI) e } \\
\text { Ibovespa ou até mesmo do valor do investimento. Devido à variação de preços e taxas ser } \\
\text { constante, a medida mais comum desse tipo de risco é a volatilidade. } \\
\text { A forma mais fácil de reduzir o risco de mercado é diversificando as aplicações em várias } \\
\text { formas de investimentos, buscando assim a maximização do retorno, através das } \\
\text { aplicações em ativos que reajam de formas diferentes aos eventos. Devido à volatilidade } \\
\text { desse tipo de risco, as ações estão sujeitas a maior risco do que os ativos de renda fixa. }\end{array}$ \\
\hline LIQUIDEZ & $\begin{array}{l}\text { Acontece devido à dificuldade ou facilidade de se desfazer do investimento. Nos } \\
\text { momentos de crise os investimentos que possuem baixa liquidez sofrem mais que aqueles } \\
\text { que possuem alta liquidez e como exemplo, normalmente os fundos de investimentos em } \\
\text { renda fixa possuem mais liquidez do que os investimentos em imóveis. Investimentos } \\
\text { como a caderneta de poupança e os fundos de investimentos possuem liquidez imediata, ou } \\
\text { seja, não estão sujeitos ao risco de liquidez e os aplicadores não terão perdas se } \\
\text { necessitarem resgatar o valor aplicado imediatamente. Já em relação às aplicações em } \\
\text { certificado de depósito bancário (CDBs), caso seja na forma pós-fixada a liquidez é } \\
\text { imediata, o que não acontece caso seja na modalidade pré-fixada. Os investimentos em } \\
\text { imóveis e/ou cotas de fundos imobiliários possuem baixa liquidez e estão sujeitos ao risco. }\end{array}$ \\
\hline CRÉDITO & $\begin{array}{l}\text { Está associado à possibilidade da falta de pagamento de uma obrigação pela outra parte, ou } \\
\text { seja, é a probabilidade de que o investidor não receba o que lhe é devido. É o risco que os } \\
\text { investidores tomam menos cuidado e geralmente suas consequências são dramáticas. Uma } \\
\text { forma de proteção contra o risco de crédito que foi criada pelo Conselho Monetário } \\
\text { Nacional - CMN em } 1995 \text { foi o Fundo Garantidor de Crédito - FGC, o qual garante no } \\
\text { caso de falência das instituições financeiras emissoras, os investimentos em depósitos a } \\
\text { vista na conta corrente e os depósitos a prazo como Recibos de Depósito Bancário } \\
\text { (RDBs), certificado de depósito bancário (CDBs), Poupança, Letras de Câmbio, Letras } \\
\text { Imobiliárias e Hipotecárias, porém é necessário cuidado e atenção, pois a garantia está } \\
\text { limitada ao valor total de R } \$ 70.000,00 \text { por CPF, desta forma há perda do excedente a esse } \\
\text { valor. } \\
\text { Esse é mais um dos tipos de riscos, aos quais os Fundos de Investimentos não estão } \\
\text { sujeitos, já os outros tipos de investimentos citados no parágrafo anterior sofrem } \\
\text { diretamente com a falência do banco emissor, pois seus recursos serão utilizados para } \\
\text { pagamento de obrigações junto ao governo e credores, passando a fazer parta de massa } \\
\text { falida da instituição. }\end{array}$ \\
\hline OPERACIONAL & $\begin{array}{l}\text { Está ligado às falhas e/ou fraudes no processamento de operações, bem como da utilização } \\
\text { de sistemas inadequados. Uma forma de evitar e/ou se livrar desse risco é procurar } \\
\text { conhecer bem a aplicação antes de investir. No Brasil uma das aplicações que estão menos } \\
\text { sujeitas a esse risco, no tocante às fraudes, é também o fundo de investimento, devido à } \\
\text { segurança na administração do mesmo, o qual deve ser administrado por um tripé } \\
\text { contendo três participantes sendo eles o Gestor, o Custodiante e o Administrador. } \\
\text { O Gestor é responsável pela estratégia de investimentos que será seguida pelo fundo e } \\
\text { também pela compra e venda de ativos, ao tempo que a função do custodiante é de guarda } \\
\text { e liquidação física e financeira dos ativos do fundo e de possíveis eventos e por fim o } \\
\text { administrador cuida do funcionamento do fundo e dos prestadores de serviço como o } \\
\text { custodiante, gestor e auditor. }\end{array}$ \\
\hline LEGAL & $\begin{array}{l}\text { Está associado à legalidade das operações, ou seja, se o contrato e suas cláusulas têm } \\
\text { validade jurídica. No Brasil, um exemplo de situação que demonstra esse tipo de risco é o } \\
\text { risco de se aplicar em uma entidade que não está autorizada e realizar a captação, mas } \\
\text { mesmo assim o faz. Há algumas dicas para evitar esse risco como: Aplicar os recursos em } \\
\text { instituições conhecidas e reconhecidas como sérias, entrar em contato com a Comissão de } \\
\text { Valores Mobiliários - CVM e questionar se ela está autorizada a captar investimentos e } \\
\text { desconfiar sempre de "milagres" principalmente nos investimentos. }\end{array}$ \\
\hline
\end{tabular}


Alternativas de investimentos às pessoas físicas e o perfil de investidor dos acadêmicos de ciências contábeis da UNEMAT, campus de Tangará da Serra-MT

Gabriel Batista da Silva

Flavio Amaral Oliveira

Fonte: Adaptado EID JUNIOR (2012).

\subsection{Perfil do Investidor}

Conforme entendimento de Cadore (2007), o fator chave necessário para que o agente financeiro possa exercer o seu papal de intermediador financeiro é a captação de recursos e o objetivo da intermediação só será atingido caso o lucro seja alcançado. Sendo assim, é necessário conhecer o perfil dos investidores proporcionando assim melhores condições para adequação dos produtos às necessidades dos mesmos, possibilitando também a rentabilidade desejada. Entretanto, frente à diversidade de alternativas de investimentos disponíveis no mercado financeiro, torna-se cada vez mais difícil para os investidores tomarem decisões, inclusive para aqueles que conhecem o mercado.

Nesse mesmo sentido, Ferreira et al (2008), entendem que a base para tomada de decisão por parte dos investidores tendo em vista os diversos tipos de investimentos oferecidos pelo mercado, principalmente no mercado acionário, reside na disponibilidade de recursos, no risco, no tempo de resgate e na rentabilidade. Ainda sob a perspectiva dos autores o perfil desses investidores é definido através da reação diante dessa diversidade de variáveis, as quais os mesmos estão sujeitos, ou até mesmo diante da combinação entre elas.

Existe uma interligação entre rentabilidade e risco, de forma que para se alcançar maior rentabilidade é necessário correr maiores riscos. Porém cada investidor possui um perfil de risco diferente, o qual está ligado ao nível de tolerância ao risco, como exemplo, para o investidor do tipo conservador é mais importante manter o seu capital intacto e lucrar menos do que correr o risco de não obter rentabilidade e ou até ter prejuízos. Por outro lado, para o investidor com perfil arrojado, é mais importante obter ganhos superiores à variação do dólar, à inflação ou ao índice das bolsas de valores (CADORE, 2007).

De acordo com informações disponíveis na internet no site da Corretora Oliveira Franco, são três os perfis de investidores, sendo eles:

a) Conservador: Este perfil pertence aos investidores que almejam rendimentos reais positivos, acima da inflação, aceitando assim variações nos retornos. Entretanto não admitem que seu patrimônio seja comprometido em médio prazo devido a possíveis instabilidades. Esse tipo de investidor almeja o lucro, porém seu objetivo principal é não perder dinheiro e a tolerância a riscos é bem baixa. 
Alternativas de investimentos às pessoas físicas e o perfil de investidor dos acadêmicos de ciências contábeis da UNEMAT, campus de Tangará da Serra-MT

Gabriel Batista da Silva

Flavio Amaral Oliveira

b) Moderado: O objetivo dos investidores com este perfil é alcançar o equilíbrio entre rendimento e crescimento com variações moderadas. Estão dispostos a se exporem mais aos riscos procurando alcançar ganhos adicionais a médio e longo prazo.

c) Agressivo: Mostra que os investidores estão dispostos a arriscarem bem mais, ou seja, possuem uma tolerância maior aos riscos e o objetivo principal deles é alcançar o crescimento do capital em curto prazo. Normalmente, investidores com este perfil tendem a assumir riscos que investidores conservadores e moderados não o faria, sempre objetivando uma maior taxa de rentabilidade.

O Banco Santander também considera que são três os perfis de investidores sendo eles: Conservador, Moderado e Arrojado. Logo abaixo a tabela 3 contém informações, retiradas diretamente do site da instituição, a respeito dos perfis de investimentos com relação aos fatores objetivo, nível de tolerância a riscos e prazo desejado para se investir.

Tabela 3. Perfis de Investidores X Objetivo X Tolerância a Riscos X Prazos.

\begin{tabular}{|c|c|c|c|}
\hline & Conservador & Moderado & Arrojado/Agressivo \\
\hline Objetivo & $\begin{array}{l}\text { Preservação de } \\
\text { Capital }\end{array}$ & $\begin{array}{l}\text { Clientes dispostos a correr } \\
\text { algum risco em seus } \\
\text { investimentos, buscando } \\
\text { um retorno diferenciado no } \\
\text { médio prazo. }\end{array}$ & $\begin{array}{l}\text { Clientes dispostos a aceitar as } \\
\text { oscilações características dos } \\
\text { mercados de risco (e } \\
\text { possíveis perdas) na busca } \\
\text { por retornos diferenciados. }\end{array}$ \\
\hline Tolerância a Riscos & Baixa & Média & Alta \\
\hline Horizonte de Tempo & Curto Prazo & Médio Prazo & Longo Prazo \\
\hline
\end{tabular}

Fonte: Banco Santander, (2013).

\section{METODOLOGIA}

Para apresentar as informações sobre as alternativas de investimentos, os riscos envolvidos e os perfis de investidores, adotou-se a metodologia de natureza exploratória. E quando procurou identificar o perfil investidor dos acadêmicos, a natureza da pesquisa foi classificada como descritiva. A esse respeito, Prodanov e Freitas (2013), coloca que a pesquisa exploratória tem a finalidade de proporcionar mais informações sobre o que vai se pesquisar ou descobrir um novo enfoque para o assunto e a pesquisa descritiva observa, registra, analisa e ordena dados, sem manipulá-los, isto é, sem interferência do pesquisador.

Quanto aos procedimentos esta pesquisa classificou-se como bibliográfica e de campo, Prodanov e Freitas (2013), consideram pesquisa bibliográfica quando é elaborada a partir de 
Alternativas de investimentos às pessoas físicas e o perfil de investidor dos acadêmicos de ciências contábeis da UNEMAT, campus de Tangará da Serra-MT

Gabriel Batista da Silva

Flavio Amaral Oliveira

material já publicado, formado por livros, revistas, publicações em periódicos e artigos científicos, jornais, boletins, monografias, dissertações, teses, internet [...]. Consideram também que a pesquisa de campo é realizada quando se procura conseguir informações e/ou conhecimentos sobre o problema que se quer encontrar a resposta, ou de uma hipótese, que se deseja comprovar, ou, ainda, encontrar novos fenômenos e suas inter-relações. Nesse tipo de pesquisa, com abordagem quantitativa, o pesquisador está limitado a descrever os fatos dos dados coletados, e ignora a complexidade da realidade social.

Quanto à abordagem do problema, a pesquisa classificou-se como qualitativa e quantitativa onde Dantas e Cavalcante (2006), definem que a pesquisa qualitativa é aquela que tem caráter exploratório, que estimula o entrevistado a pensar livremente sobre algum conceito, tema ou objeto, que busca percepções e entendimento sobre uma questão, proporcionando a interpretação e ainda ao pesquisador desenvolver conceitos, ideias e entendimentos [...]. Já a pesquisa quantitativa utiliza-se de questionários para mensurar resultados quantificáveis de variáveis e inferências a partir de amostras numéricas ou busca nos conceitos cotidianos padrões numéricos.

As informações foram obtidas através de referências bibliográficas, e por meio de questionários (fechados) aplicados junto a amostra de 108 acadêmicos distribuídos no $6^{\circ}, 7^{\circ} \mathrm{e}$ $8^{\circ}$ semestres do curso de Ciências Contábeis da UNEMAT, campus de Tangará da Serra MT, onde 71 acadêmicos responderam ao questionário. Para administração do tempo, esta pesquisa foi realizada apenas com os acadêmicos dos três últimos semestres do curso e também por eles estar a mais tempo na universidade.

As primeiras 08 questões do questionário identificaram-se dados demográficos dos acadêmicos (sexo, idade, estado civil, renda, setor profissional e etc.). Já nas questões de 09 a 16 foram identificados dados que resultaram na identificação do perfil investidor dos mesmos.

No curso de ciências contábeis existem atualmente 365 acadêmicos matriculados e a pesquisa foi realizada nas seguintes disciplinas: Contabilidade das Instituições Financeiras $\left(6^{\circ}\right.$ sem) com 36 matriculados e 27 respondentes; Contabilidade Tributária ( $7^{\circ}$ sem) com 40 matriculados e 26 respondentes; e Contabilidade Avançada ( $\left.8^{\circ} \mathrm{sem}\right)$ com 32 matriculados e 18 respondentes.

Para apuração dos resultados da tabela 14 , nas escolhas $\left(1^{\mathrm{a}}, 2^{\mathrm{a}}, 3^{\mathrm{a}}, 4^{\mathrm{a}}, 5^{\mathrm{a}}\right.$ e $\left.6^{\mathrm{a}}\right)$ atribuiuse, respectivamente, os pesos $(6,5,4,3,2$ e 1). Por exemplo, caso a poupança fosse escolhida como $1^{\text {a }}$ escolha e os fundos de investimentos como $2^{\text {a }}$ escolha, receberia os pesos 6 e 5 
Alternativas de investimentos às pessoas físicas e o perfil de investidor dos acadêmicos de ciências contábeis da UNEMAT, campus de Tangará da Serra-MT

Gabriel Batista da Silva

Flavio Amaral Oliveira

respectivamente. Após a apuração das escolhas, multiplicaram-se cada escolha pelo seu respectivo peso e logo após fez-se o somatório que cada opção de investimento atingiu. Desta forma, o investimento com maior pontuação foi classificado como o mais escolhido em $1^{\mathrm{a}}$ escolha; o que atingiu a segunda maior pontuação como o mais escolhido em $2^{\mathrm{a}}$ escolha e assim sucessivamente até chegar àquele que atingiu a menor pontuação classificando-o como o mais escolhido em $6^{\mathrm{a}}$ ou última escolha pelos acadêmicos.

Da mesma forma, para apuração dos resultados da tabela 15, foram atribuídos pesos de 5 a 1 para os riscos escolhidos como mais relevantes. Assim, caso o acadêmico escolhesse o risco de crédito em $1^{\circ}$ lugar, e o risco de liquidez em $2^{\circ}$ lugar, esses riscos receberiam os pesos 5 e 4 respectivamente. Após a apuração das escolhas dos acadêmicos e atribuição dos pesos, somaram-se quantos pontos cada tipo de risco atingiu e considerou-se como mais relevante aquele com maior pontuação; como $2^{\mathrm{o}}$ mais relevante aquele $\operatorname{com} 2^{\mathrm{a}}$ maior pontuação e assim sucessivamente até chegar aquele com menor pontuação classificando-o como o risco menos relevante a ser considerado na hora de investir.

\section{DISCUSSÃO E RESULTADOS}

Logo abaixo estão demonstrados os resultados, através de tabelas, encontrados na pesquisa realizada junto aos acadêmicos.

Tabela 4. Público pesquisado, por turma e gênero

\begin{tabular}{lccccc}
\hline Gênero & $\mathbf{6}^{\mathbf{0}} \mathbf{\text { sem. }}$ & $\mathbf{7}^{\mathbf{0}} \mathbf{\text { sem. }}$ & $\mathbf{8}^{\mathbf{0}}$ sem. & Total & $\mathbf{( \% )}$ \\
\hline Feminino & 16 & 12 & 13 & 41 & 57,75 \\
Masculino & 11 & 14 & 5 & 30 & 42,25 \\
Total & $\mathbf{2 7}$ & $\mathbf{2 6}$ & $\mathbf{1 8}$ & $\mathbf{7 1}$ & $\mathbf{1 0 0}$ \\
\hline
\end{tabular}

Fonte: dados da pesquisa

Conforme a tabela 4 acima, as mulheres representam a maioria do público pesquisado, elas são $57,75 \%$ do total, enquanto os homens somam $42,25 \%$.

Tabela 5. Público pesquisado, por estado civil

\begin{tabular}{lccccc}
\hline Est. Civil & $\mathbf{6}^{\mathbf{0}} \mathbf{~ s e m . ~}$ & $\mathbf{7}^{\mathbf{0}}$ sem. & $\mathbf{8}^{\mathbf{o}}$ sem. & Total & $(\boldsymbol{\%})$ \\
\hline Solteiro & 18 & 15 & 12 & 45 & 63,38 \\
Casado/Rel. Estável & 9 & 10 & 5 & 24 & 33,8 \\
Separado/Divorciado & - & 1 & 1 & 2 & 2,82 \\
Total & $\mathbf{2 7}$ & $\mathbf{2 6}$ & $\mathbf{1 8}$ & $\mathbf{7 1}$ & $\mathbf{1 0 0}$ \\
\hline
\end{tabular}

Fonte: dados da pesquisa

A tabela 5 acima mostra que do total (71) de acadêmicos que responderam, a maioria, $63,38 \%$ se declarou solteiro, enquanto $33,80 \%$ se declararam casados ou com união estável, e a minoria, somente $2,82 \%$, se declarou separado ou divorciado. 
Alternativas de investimentos às pessoas físicas e o perfil de investidor dos acadêmicos de ciências contábeis da UNEMAT, campus de Tangará da Serra-MT

Gabriel Batista da Silva

Flavio Amaral Oliveira

\begin{tabular}{lcccccc}
\hline & Tabela 6. Faixa Etária & & & \\
\hline Faixa Etária (anos) & $\mathbf{6}^{\mathbf{0}} \mathbf{~ s e m . ~}$ & $\mathbf{7}^{\mathbf{0}} \mathbf{\text { sem. }}$ & $\mathbf{8}^{\mathbf{0}}$ sem. & Total & $\mathbf{( \% )}$ \\
\hline Até 20 & 8 & 1 & 2 & 11 & 15,49 \\
De 21 a 25 & 10 & 14 & 6 & 30 & 42,25 \\
De 26 a 30 & 8 & 9 & 8 & 25 & 35,21 \\
De 31 a 35 & 1 & - & 2 & 3 & 4,23 \\
De 36 a 40 & - & 1 & - & 1 & 1,41 \\
Acima de 40 & - & 1 & - & 1 & 1,41 \\
Total & $\mathbf{2 7}$ & $\mathbf{2 6}$ & $\mathbf{1 8}$ & $\mathbf{7 1}$ & $\mathbf{1 0 0 , 0 0}$ \\
\hline
\end{tabular}

Fonte: dados da pesquisa

Conforme a tabela 6 acima, a maioria $(42,25 \%)$ dos acadêmicos possui entre 21 e 25 anos e $35,21 \%$ estão na faixa dos 26 a 30 anos.

Tabela 7. Renda Bruta Individual (solteiros) e Familiar (casados)

\begin{tabular}{lccccc}
\hline Renda Bruta & $\mathbf{6}^{\mathbf{0}} \mathbf{~ s e m}$. & $\mathbf{7}^{\mathbf{0}} \mathbf{s e m}$. & $\mathbf{8}^{\mathbf{0}} \mathbf{~ s e m}$. & Total & $\mathbf{( \% )}$ \\
\hline Não possui renda & - & - & 1 & 1 & 1,41 \\
Até R \$ 1.356,00 & 6 & 8 & 7 & 21 & 29,58 \\
De R \$ 1356,01 a R \$ 2.712,00 & 10 & 9 & 4 & 23 & 32,39 \\
De R $2.712,01$ a R $6.780,00$ & 11 & 9 & 6 & 26 & 36,62 \\
Total & $\mathbf{2 7}$ & $\mathbf{2 6}$ & $\mathbf{1 8}$ & $\mathbf{7 1}$ & $\mathbf{1 0 0 , 0 0}$ \\
\hline
\end{tabular}

Fonte: dados da pesquisa

Em relação a renda bruta, os dados da tabela 7 acima representam a renda individual para os que declararam ser solteiros e a renda familiar para os casados. Assim, 36,62\% possuem renda de $\mathrm{R} \$ 2.712,01$ a $\mathrm{R} \$ 6.780,00$ e $32,39 \%$ recebem de $R \$ 1.356,01$ a $\mathrm{R} \$$ 2.712,00.

Em relação ao setor de trabalho verificou-se que 39,44\% dos acadêmicos trabalham no comércio e outros $36,62 \%$ com prestação de serviços. A tabela que demonstra esses resultados não foi disposta no estudo por conta do espaço.

Tabela 8. Quantos poupam recursos

\begin{tabular}{lccccc}
\hline Poupar Recursos & $\mathbf{6}^{\mathbf{0}} \mathbf{s e m}$. & $\mathbf{7}^{\mathbf{0}} \mathbf{s e m}$. & $\mathbf{8}^{\mathbf{0}}$ sem. & Total & $(\boldsymbol{\%})$ \\
\hline Poderia poupar, mas não o faz & 14 & 14 & 6 & 34 & 47,89 \\
Poderia poupar e o faz & 12 & 7 & 3 & 22 & 30,99 \\
Renda insuficiente para poupar & 1 & 5 & 8 & 14 & 19,72 \\
Não possui renda & - & - & 1 & 1 & 1,41 \\
Total & 27 & 26 & 18 & 71 & 100,00 \\
\hline
\end{tabular}

Fonte: dados da pesquisa

De acordo com a tabela 8 acima, 47,89\% dos acadêmicos responderam que poderia poupar mas não o faz; 30,99\% assinalaram que podem poupar e o faz; $19,72 \%$ informaram que sua renda é insuficiente para poupar e apenas 01 acadêmico respondeu que não trabalha.

Tabela 9. Quantos já investiram e em que

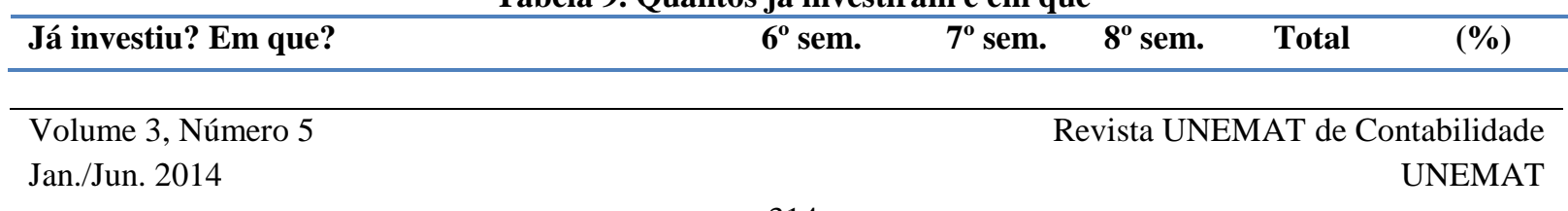


Alternativas de investimentos às pessoas físicas e o perfil de investidor dos acadêmicos de ciências contábeis da UNEMAT, campus de Tangará da Serra-MT

Gabriel Batista da Silva

Flavio Amaral Oliveira

\begin{tabular}{lccccc}
\hline Nunca investi & 6 & 17 & 11 & 34 & 47,89 \\
Caderneta de Poupança & 15 & 8 & 4 & 27 & 38,03 \\
Títulos Públicos & - & - & 2 & 2 & 2,82 \\
Fundos de Investimentos & 2 & - & 1 & 3 & 4,23 \\
CDBs e RDBs & - & - & - & 0 & - \\
Ações & - & - & - & 0 & - \\
Previdência & 2 & - & - & 2 & 2,82 \\
Outros & 2 & 1 & - & 3 & 4,23 \\
Total & 27 & 26 & 18 & 71 & 100,00 \\
\hline
\end{tabular}

Fonte: dados da pesquisa

Conforme tabela 9 acima, 47,89\% afirmaram que nunca investiram; 38,03\% informaram que investiram apenas na caderneta de poupança; Nenhum dos acadêmicos pesquisados investiu em Ações ou CDBs e RDBs até o momento.

A tabela 10 abaixo mostra os dados coletados quando se perguntou qual o objetivo financeiro os acadêmicos considerariam mais importante na hora de investir. O objetivo da pergunta foi identificar o perfil investidor dos acadêmicos.

Tabela 10. Perfil Investidor dos Acadêmicos

\begin{tabular}{lccccc}
\hline Perfil & $\mathbf{6}^{\mathbf{0}} \mathbf{s e m}$. & $\mathbf{7}^{\mathbf{0}}$ sem. & $\mathbf{8}^{\mathbf{0}}$ sem. & Total & $\mathbf{( \% )}$ \\
Conservador & 21 & 14 & 13 & 48 & 67,61 \\
Moderado & 5 & 11 & 4 & 20 & 28,17 \\
Arrojado/Agressivo & 1 & 1 & 1 & 3 & 4,23 \\
Total & 27 & 26 & 18 & 71 & 100,00 \\
\hline
\end{tabular}

Fonte: dados da pesquisa

A maioria $(67,61 \%)$ possui perfil conservador; Outros $28,17 \%$ possuem perfil moderado e apenas 03 acadêmicos $(4,23 \%)$ possuem perfil arrojado ou agressivo.

A tabela 11 abaixo contém dados encontrados quando se perguntou qual o nível de conhecimento sobre as opções de investimentos dispostas na tabela. O objetivo da pergunta foi verificar em qual investimento eles acreditam que possuem mais conhecimento e em qual possui menos conhecimento.

Tabela 11. Nível de conhecimento sobre as opções de investimentos

\begin{tabular}{c|cc|cc|cc|cc|cr|rr}
\hline Conhecimento & \multicolumn{10}{c}{ Opiniões por investimento e por nível de conhecimento } \\
\hline & Poup. & AV $(\%)$ & T. Púb. & AV $(\%)$ & FI & AV $(\%)$ & Ações & AV $(\%)$ & Prev. & AV $(\%)$ & CDB/RDB & AV(\%) \\
\hline Nenhum & 1 & 1,41 & 23 & 32,39 & 21 & 29,58 & 19 & 26,76 & 14 & 19,72 & 31 & 43,66 \\
Pouco & 7 & 9,86 & 34 & 47,89 & 34 & 47,89 & 27 & 38,03 & 25 & 35,21 & 25 & 35,21 \\
Razoável & 37 & 52,11 & 12 & 16,90 & 13 & 18,31 & 15 & 21,13 & 15 & 21,13 & 8 & 11,27 \\
Bom & 15 & 21,13 & 2 & 2,82 & 3 & 4,23 & 9 & 12,68 & 12 & 16,90 & 6 & 8,45 \\
Muito bom & 11 & 15,49 & 0 & - & 0 & - & 1 & 1,41 & 5 & 7,04 & 1 & 1,41 \\
Total & 71 & 100 & 71 & 100 & 71 & 100 & 71 & 100 & 71 & 100 & 71 & 100 \\
\hline
\end{tabular}

Fonte: dados da pesquisa

Os acadêmicos afirmam ter mais conhecimento sobre a caderneta de poupança, pois, $52,11 \%$ informaram possuir conhecimento razoável, 21,13\% informou bom, e 26,49\% muito 
Alternativas de investimentos às pessoas físicas e o perfil de investidor dos acadêmicos de ciências contábeis da UNEMAT, campus de Tangará da Serra-MT

Gabriel Batista da Silva

Flavio Amaral Oliveira

bom. Enquanto que, o menor nível de conhecimento está em CDB/RDB, com 43,66\% de marcação em nenhum conhecimento e $35,21 \%$ em pouco conhecimento. Conforme informações disposta na Tabela 1, a poupança e os CDBs e RDBs são investimentos de renda fixa, de baixo risco, acessíveis à população através dos bancos, desta forma acredita-se que não são investimentos que necessitem de muito conhecimento para se investir.

Os outros investimentos tiveram maior afirmação em pouco e nenhum conhecimento, portanto, na opinião dos acadêmicos, em resumo, conclui-se que na maioria dos investimentos o nível de conhecimento está entre nenhum e razoável. Essa pode ser uma possível explicação para o percentual de $47,89 \%$ não ter investido em nenhum investimento outros $38,03 \%$ ter investido apenas na poupança.

A tabela 12 mostra abaixo os dados ao perguntar qual investimento dos dispostos abaixo oferece maior risco e qual oferece maior rentabilidade ao investidor na opinião dos acadêmicos. Buscou-se verificar o conhecimento sobre risco e rentabilidade.

Tabela 12. Opções de Investimentos com maior risco e maior rentabilidade.

\begin{tabular}{|c|c|c|c|c|c|}
\hline Maior Risco & $6^{\circ}$ sem. & $7^{\circ}$ sem. & $8^{\circ}$ sem. & Total & $(\%)$ \\
\hline Ações & 26 & 17 & 13 & 56 & 78,87 \\
\hline Fundos de Investimentos & - & 3 & 1 & 4 & 5,63 \\
\hline CDBs e RDBs & - & 2 & 1 & 3 & 4,23 \\
\hline Caderneta de Poupança & - & 2 & - & 2 & 2,82 \\
\hline Títulos Públicos & 1 & 1 & - & 2 & 2,82 \\
\hline Previdência Privada & - & - & 1 & 1 & 1,41 \\
\hline Não responderam & - & 1 & 2 & 3 & 4,23 \\
\hline Total & 27 & 26 & 18 & 71 & 100,00 \\
\hline \multicolumn{6}{|l|}{ Maior Rentabilidade } \\
\hline Ações & 16 & 14 & 6 & 36 & 50,70 \\
\hline Fundos de Investimentos & 3 & 4 & 3 & 10 & 14,08 \\
\hline Caderneta de Poupança & 2 & 4 & 3 & 9 & 12,68 \\
\hline Títulos Públicos & 2 & 3 & 2 & 7 & 9,86 \\
\hline CDBs e RDBs & 4 & - & 1 & 5 & 7,04 \\
\hline Não responderam & - & 1 & 3 & 4 & 5,63 \\
\hline Total & 27 & 26 & 18 & 71 & 100,00 \\
\hline
\end{tabular}

Fonte: dados da pesquisa

$78,87 \%$ dos acadêmicos acreditam que a opção que apresenta maior risco na hora de investir, são as ações. E 50,70\% afirmaram que as ações é também a opção que oferece maior rentabilidade. 
Alternativas de investimentos às pessoas físicas e o perfil de investidor dos acadêmicos de ciências contábeis da UNEMAT, campus de Tangará da Serra-MT

Gabriel Batista da Silva

Flavio Amaral Oliveira

A tabela 13 mostra o resultado quando perguntado qual seria a primeira escolha de investimento caso o acadêmico possuísse $\mathrm{R} \$ 10.000,00$ de recursos poupados. Essa pergunta buscou identificar qual seria a opção mais escolhida.

Tabela 13. Primeira escolha de investimento, considerando $\mathbf{R} \$ \mathbf{1 0 . 0 0 0 , 0 0}$ de recursos poupados.

\begin{tabular}{lccccc}
\hline Escolhas & $\mathbf{6}^{\mathbf{0}} \mathbf{s e m}$. & $\mathbf{7}^{\mathbf{0}} \mathbf{s e m}$. & $\mathbf{8}^{\mathbf{0}} \mathbf{s e m}$. & Total & $\mathbf{( \% )}$ \\
\hline Caderneta de Poupança & 9 & 12 & 11 & 32 & 45,07 \\
Imóveis & 7 & 5 & - & 12 & 16,90 \\
Ações & 2 & 2 & 1 & 5 & 7,04 \\
Outros (carros, motocicletas, mobília e etc.) & 3 & 1 & 1 & 5 & 7,04 \\
CDBs e RDBs & 1 & 2 & 1 & 4 & 5,63 \\
Fundos de Investimentos & 1 & 1 & 2 & 4 & 5,63 \\
Títulos Públicos & 2 & 1 & 1 & 4 & 5,63 \\
Previdência & 2 & - & 1 & 3 & 4,23 \\
Não responderam & - & 2 & - & 2 & 2,82 \\
Total & 27 & 26 & 18 & 71 & 100,00 \\
\hline
\end{tabular}

Fonte: dados da pesquisa

Assim, verifica-se que a caderneta de poupança e os imóveis foram as duas opções mais escolhidas representadas respectivamente por $45,07 \%$ e $16,90 \%$.

Caso considere $\mathrm{R} \$ 1.000 .000,00$ de recursos poupados, os resultados mostraram que $28,17 \%$ dos acadêmicos escolheram a poupança e outros $28,17 \%$ as ações como primeira escolha. Nas duas simulações, com $\mathrm{R} \$ 10.000,00$ e $\mathrm{R} \$ 1.000 .000,00$, a poupança foi a opção mais escolhida pelos acadêmicos, fato esse que confirma o perfil conservador da maioria dos pesquisados conforme tabela 10 .

A tabela 14 abaixo demonstra os resultados encontrados quando solicitado que escolhessem dentre as seis alternativas abaixo, quais seriam as principais escolhas de investimento considerando $\mathrm{R} \$ 1.000 .000,00$ de recursos poupados. O objetivo também foi verificar a preferência dos acadêmicos.

Tabela 14. Principais escolhas de investimentos, considerando $R \$ 1.000 .000,00$ de recursos poupados.

\begin{tabular}{lcc}
\hline Escolhas & Opções de Investimento & Pontuação Total \\
\hline Primeira & Caderneta de Poupança & 325 \\
Segunda & Ações & 279 \\
Terceira & Títulos Públicos & 263 \\
Quarta & Fundos de Investimentos & 230 \\
Quinta & Previdência Privada & 203 \\
Sexta & CDBs e RDBs & 150 \\
\hline
\end{tabular}

Fonte: dados da pesquisa

A opção preferida dos acadêmicos foi a caderneta de poupança e a opção menos escolhida foram os CDBs e RDBS, situação essa que pode estar relacionada ao resultado encontrado na tabela 11 , onde $43,66 \%$ dos acadêmicos responderam que não possuem 
Alternativas de investimentos às pessoas físicas e o perfil de investidor dos acadêmicos de ciências contábeis da UNEMAT, campus de Tangará da Serra-MT

Gabriel Batista da Silva

Flavio Amaral Oliveira

conhecimento algum sobre os CDBs e RDBs e a poupança foi escolhida como aquela que eles possuem mais conhecimento.

Considerando apenas $\mathrm{R} \$ 10.000,00$ de recursos poupados, a opção mais escolhida continuou sendo a caderneta de poupança e a menos escolhida os CDBs e RDBs, por conta do espaço insuficiente os dados não foram demonstrados através de tabela, somente comentados.

A tabela 15 abaixo procurou mostrar o nível de relevância dos tipos de riscos conforme opinião dos acadêmicos.

Tabela 15. Nível de Relevância dos Tipos de Riscos por Pontos

\begin{tabular}{lcccc}
\hline Tipos de Risco & $\mathbf{6}^{\mathbf{0}} \mathbf{\text { sem. }}$ & $\mathbf{7}^{\mathbf{0}} \mathbf{\text { sem. }}$ & $\mathbf{8}^{\mathbf{0}}$ sem. & Pontuação Total \\
Risco Legal & 95 & 85 & 38 & 218 \\
Risco de Liquidez & 78 & 88 & 45 & 211 \\
Risco de Crédito & 69 & 88 & 42 & 199 \\
Risco de Mercado & 85 & 66 & 44 & 195 \\
Risco Operacional & 73 & 65 & 41 & 179 \\
Não responderam & 1 & 1 & 4 & 6 \\
\hline
\end{tabular}

Fonte: dados da pesquisa

O risco legal foi escolhido como mais relevante com 218 pontos e o risco operacional menos relevante com 179 pontos. Considerando o resultado total encontrado, pode-se afirmar que grande parte dos acadêmicos não conhece os riscos, uma vez que consideraram o risco legal mais relevante, e conforme Eid Júnior (2012), o risco legal, bem como o operacional são os riscos que podem ser facilmente evitáveis. Caso leve-se em conta o resultado por semestre, verifica-se que os acadêmicos do $7^{\circ}$ e $8^{\circ}$ semestres conhecem melhor os riscos do que os do $6^{\circ}$, pois consideraram mais relevantes os riscos de crédito e liquidez e menos relevantes o risco legal e operacional.

\section{CONCLUSÃO}

No levantamento bibliográfico desta pesquisa encontrou-se um estudo realizado por Andreatta et al em 2009, que buscou apresentar alternativas de investimentos para pessoas físicas, especificamente, o estudo levantou as principais escolhas de 29 investidores patobranquenses e realizou um comparativo de retorno no período de janeiro de 2007 a setembro de 2009 das três principais escolhas encontradas, onde verificou-se que as ações foram a opção escolhida pelos investidores que apresentaram maior rentabilidade. Os autores verificaram ainda que o perfil de investidor que prevaleceu entre os investidores foi o conservador. 
Alternativas de investimentos às pessoas físicas e o perfil de investidor dos acadêmicos de ciências contábeis da UNEMAT, campus de Tangará da Serra-MT

Gabriel Batista da Silva

Flavio Amaral Oliveira

Este estudo foi realizado com base no estudo citado acima. Entretanto, limitou-se através de seu objetivo geral a apresentar alternativas de investimentos para pessoas físicas e identificar o perfil de investidor dos acadêmicos do Curso de Ciências Contábeis da UNEMAT, campus de Tangará da Serra/MT.

Assim, os objetivos desta pesquisa foram atingidos, pois, em relação ao objetivo geral destacou-se 06 (seis) opções de investimentos sendo elas: Caderneta de Poupança; Títulos Públicos; Fundos de Investimentos; Ações; CDBs e RDBs e Previdência Privada. E identificou-se que na maioria dos acadêmicos pesquisados $(67,61 \%)$ o perfil de investidor que prevaleceu foi o conservador; o perfil moderado foi encontrado em $28,17 \%$ e o perfil arrojado ou agressivo esteve presente em apenas $4,23 \%$ dos acadêmicos.

Em relação aos objetivos específicos, destacou-se 05 (cinco) tipos de riscos sendo eles: Risco de Mercado; de Liquidez; de Crédito; Operacional; e Legal. E apresentaram-se ainda informações sobre as formas de acesso aos investimentos (bancos, corretoras, bolsas de valores, tesouro direto, seguradoras, etc.); E algumas informações sobre custos (IR, IOF, taxas etc.); E sobre os perfis de investidores identificou-se 03 (três) tipos, sendo eles: conservador; moderado; e arrojado ou agressivo.

Assim, fica aberto o espaço para que novas pesquisas sejam desenvolvidas nesta área de investimentos, uma vez que este estudo não se encerra por si só. Como sugestão para novas pesquisas, poderá se pesquisar sobre a influência das taxas de juros sobre os investimentos; Sobre quais investimentos apresentam maior rentabilidade; e/ou sobre o nível de conhecimento de acadêmicos sobre o mercado financeiro e opções de investimentos.

\section{REFERÊNCIAS}

ANDREATTA, Ana Paula; PIGOSSO, Denise; BADIA, Maurício; SCHVIRCK, Prof. M. Sc. Eliandro. Alternativa de Investimentos para Pessoa Física: Mercado Financeiro Brasileiro.

Revista e-Estudante - Eletronic Accounting and Management, Paraná, v. 2, n. 2, UTFPR, 2010. ISSN 1984-7378.

BANCO CENTRAL DO BRASIL. FAQ - Aplicações Financeiras. 2013. Disponível em: <http://www.bcb.gov.br/?APLICACOESFAQ>. Acesso em: 02/10/2013.

BOVESPA. Capítulo 4 - Mercado e Títulos de Renda Fixa no Brasil. 2012. Disponível em: $<$ http://www.portaldoinvestidor.gov.br/menu/primeiros_passos/Investindo/Tipos_Investiment o/CDB_RDB.html>. Acesso em: 03/10/2013.

BOVESPA. Fundos de Investimentos. 2012. Disponível em:

<http://lojavirtual.bmf.com.br/LojaIE/portal/pages/pdf/Apostila_PQO_Cap_07_V2.pdf>. Acesso em: 01/10/2013. 
Alternativas de investimentos às pessoas físicas e o perfil de investidor dos acadêmicos de ciências contábeis da UNEMAT, campus de Tangará da Serra-MT

Gabriel Batista da Silva

Flavio Amaral Oliveira

CADORE, Rosmari Bertolo. Perfil do investidor diante do portfólio de possibilidades para investimentos financeiros no Banco do Brasil agência de Xaxim. 2007. S.C.

Disponível em:

<http://www.lume.ufrgs.br/bitstream/handle/10183/14196/000649744.pdf?sequence=1>. Acesso em: 27/03/2013.

CAIXA ECONÔMICA FEDERAL. Porque Investir. 2013. Disponível em:

<http://www11.caixa.gov.br/portal/public/investidor/investidor/aprenda/porque_investir>.

Acesso em: 06/04/2013.

CAIXA ECONOMICA FEDERAL. Poupança. 2013. Disponível em:

<http://www.caixa.gov.br/Voce/poupanca/historia.asp>. Acesso em: 30/09/2013.

CARNEIRO, Márcio. Investimentos financeiros e seus riscos (mercado, crédito e

liquidez). 2012. Disponível em: <http://www.administradores.com.br/artigos/administracaoe-negocios/investimentos-financeiros-e-seus-riscos-mercado-credito-e-liquidez/63627/> .

Acesso em: 18/03/2013.

CARNEIRO, Murilo. Previdência Privada: conceito e características. 2013. Disponível em: <http://www.revide.com.br/blog/murilo/post/previdencia-privada-conceito-ecaracteristicas/>. Acesso em: 05/10/2013.

COMISSÃO DE VALORES MOBILIARIOS. CDB's e RDB's. 2013. Disponível em: $<$ http://www.portaldoinvestidor.gov.br/menu/primeiros_passos/Investindo/Tipos_Investiment o/CDB_RDB.html>. Acesso em: 03/10/2013.

COMISSÃO DE VALORES MOBILIARIOS. Cotas de Fundos de Investimentos (409). 2013. Disponível em:

<http://www.portaldoinvestidor.gov.br/menu/Menu_Investidor/valores_mobiliarios/FundodeI nvestimento409.html>. Aceso em 02/10/2013.

D’AGOSTO, Marcelo. Conheça os riscos dos seus investimentos. 2011. Disponível em: $<$ http://www.valor.com.br/valor-investe/o-consultor-financeiro/1003936/conheca-os-riscosdos-seus-investimentos>. Acesso em: 19/03/2013.

DANTAS, Marcelo; CAVALCANTE, Vanessa. Pesquisa qualitativa e pesquisa quantitativa. 2006. Disponível em: <http://pt.scribd.com/doc/14344653/Pesquisa-qualitativae-quantitativa>. Acesso em: 05/10/2013.

DEBIASI, Cristiano Minuzzi. O mercado de Previdência Privada no Brasil: análise das melhores alternativas de investimento previdenciário. Revista de Ciências da Administração, Santa Catarina, v.6, n.12, jul/dez 2004.

EID JUNIOR, William. Longo prazo, Poupança das Famílias e os Fundos de Investimento. 2012. Disponível em:

<http://cef.fgv.br/sites/cef.fgv.br/files/file/Estudo\%20V.pdf>. Acesso em: 02/10/2013.

EID JÚNIOR, William. Risco nas aplicações financeiras e os fundos de investimento.

2012. Disponível em: <http://cef.fgv.br/sites/cef.fgv.br/files/file/Estudo\%20VIII.pdf>. Acesso em: 26/09/2013 
Alternativas de investimentos às pessoas físicas e o perfil de investidor dos acadêmicos de ciências contábeis da UNEMAT, campus de Tangará da Serra-MT

Gabriel Batista da Silva

Flavio Amaral Oliveira

FERREIRA, Andréia Franklin; TANOHIRA, Joice G. N.; SIPIER, Sônia Mendes S.;

GARCIA, Elias. Investimentos - Análise das decisões de investimentos sob uma visão gerencial e contábil. 2008. Disponível em:

<http://www.unioeste.br/campi/cascavel/ccsa/VIISeminario/contabilidade/artigo21.pdf>.

Acesso em: 05/10/2013.

FERREIRA, Marco Aurélio M.; GROSSI, Roseane; LEAL, Crislene; SILVEIRA, Suely de Fátima R. Perfil de Investidores e Formação de Portfólios: Contribuições a partir da Análise Multivariada de Dados. Revista de Negócios, Blumenau, v13, n. 1, p. 45 - 59, Janeiro/março 2008. ISSN 1980-4431.

FRANCO, Oliveira. Análise do Perfil do Investidor. 2013. Disponível em: <http://www.ofranco.com.br/conteudo.asp?cod=86>. Acesso em: 25/09/2013.

FRANCO, Wilson Oliveira. Desmistificando os Títulos Públicos. 2010. Disponível em: $<$ http://www.santacruz.br/v4/download/janela-

economica/2010/13_Desmistificando_os_Titulos_Publicos.pdf> Acesso em: 01/10/2013.

LIRA, Camila de. Mercado de Capitais: Brasil tem menos investidores que Colômbia e Panamá. 2012. Disponível em: <http://www.executivosfinanceiros.com.br/financas/brasiltem-menos-investidores-que-colombia-e-panama>. Acesso em: 25/09/2013.

MARTINS, Leandro. Desvantagens dos planos de previdência privada. 2013. Disponível em: $<$ http://www.seuconsultorfinanceiro.com.br/artigos_investimento.php?secao=43\&paramet ro=1842>. Acesso em: 05/10/2013.

MARTINS, Leandro. Qual utilizar: Análise Fundamentalista ou Análise Gráfica para investir em ações. 2013. Disponível em:

$<$ http://www.seuconsultorfinanceiro.com.br/artigos_investimento.php?secao=43\&parametro= 1836>. Acesso em: 05/10/2013.

PRODANOV, Cleber Cristiano; FREITAS, Ernani Cesar de. Metodologia do Trabalho Científico: Métodos e Técnicas de Pesquisa e do Trabalho Acadêmico. 2. Ed. Novo Hamburgo: Feevale. 2013. Disponível em:

$<$ http://docente.ifrn.edu.br/valcinetemacedo/disciplinas/metodologia-do-trabalho-cientifico/ebook-mtc>. Acesso em: 20/11/2013.

ROCHA, André. A estagnação da bolsa: falta investidores ou cias? 2013. Disponível em: $<$ http://www.valor.com.br/valor-investe/o-estrategista/3068560/estagnacao-da-bolsa-faltaminvestidores-ou-cias>. Acesso em: 25/09/13.

SANTANDER. O que é análise de perfil do investidor. 2013. Disponível em:

<http://www.santander.com.br/portal/gsb/gcm/package/asset_management/suitability_49179. zip/home.htm>. Acesso em: 28/09/2013.

SANTOS. André. O que é uma ação e quais os diferentes tipos? 2011. Disponível em: $<$ http://www.investidoriniciante.com.br/2011/02/o-que-e-uma-acao-e-quais-os-diferentestipos/>. Acesso em: 05/10/2013. 
Alternativas de investimentos às pessoas físicas e o perfil de investidor dos acadêmicos de ciências contábeis da UNEMAT, campus de Tangará da Serra-MT

Gabriel Batista da Silva

Flavio Amaral Oliveira

TESOURO NACIONAL. O que são títulos públicos? 2013. Disponível em:

<https://www.tesouro.fazenda.gov.br/pt/o-que-sao-titulos-publicos>. Acesso em: 30/09/2013.

UOL - Universo Online Livre. Conheça 4 investimentos que são livres do IR, assim como a poupança. 2012. Disponível em: <http://economia.uol.com.br/financas-

pessoais/noticias/redacao/2012/12/19/conheca-4-investimentos-que-sao-livres-do-ir-assimcomo-a-poupanca.htm>. Acesso em: 30/09/2013.

VERÍSSIMO, Márcio. Relações com Investidores: Investidores Individuais no Brasil.

2013. Disponível em: <http://www.mzweb.com.br/mz/web/arquivos/MZ_280305_port.pdf〉. Acesso em: 26/09/2013.

VIEIRA, Marcello. Mercado Financeiro. 2013. Disponível em:

<http://investimentoemacoes.com/mercado-financeiro/>. Acesso em: 24/09/2013. 